\title{
Genealogía de la categoría de colono: imágenes y representaciones en las zonas de frontera y su devenir en campesino colono y campesino cocalero
}

\author{
Genealogy of the category colono: its images and \\ representations in frontier regionas and its rendition \\ as campesino colono and campesino cocalero
}

\author{
María Clemencia Ramírez \\ Instituto Colombiano de Antropología e Historia, Colombia
}

DOI: $10.22380 / 2539472 X .2002$

\begin{abstract}
$\overline{\text { RESUMEN }}$
Este es un artículo de revisión de literatura en el que exploro el uso de la categoría de colono por parte del Gobierno colombiano y de algunos académicos, así como las imágenes asociadas a esta, contrastando la frontera interna con los territorios nacionales. Argumento que el peso histórico de la colonización del oriente del país como una solución alterna a la reforma agraria en su interior ha llevado a que la categoría de colono sea excluyente para aquellos a quienes se les adscribe, al despojarlos de su condición de campesinos. Más específicamente, esta exclusión se profundiza cuando se trata de cultivadores de coca y cuando la categoría de colono se sustituye por la de colono cocalero, lo cual criminaliza y estigmatiza, además de que niega la identidad como campesino y, así, previene su constitución como tal.
\end{abstract}

Palabras clave: colonización, colono, campesino cocalero, campesino colono, Amazonía occidental.

\section{ABSTRACT}

This is a review of the literature in which I explore the use of the category colono (settler), in addition to the images associated with it, by the Colombian government and by some researchers, contrasting its use with reference to the internal frontier with that of national territories. I argue that the historical weight of settling the eastern part of the country as an alternative to agrarian reform has led to a situation wherein those described as colonos are stripped of their identity as campesinos. This process is compounded when referring to those who grow coca and when the phrase colono cocalero is used in place of colono, criminalizing and stigmatizing such subjects and also denying their identity as campesinos, which impedes their constitution as such.

Keywords: colonization, colono (setter), campesino cocalero (coca grower), campesino colono, Western Amazonian region. 


\section{Introducción}

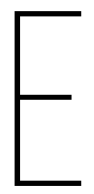

n este artículo me propongo trazar una genealogía de algunos procesos de colonización relevantes que ha vivido Colombia, con el fin de analizar cómo se construye y qué valores se le asignan a la categoría de colono, tanto por parte del Gobierno/Estado como de los académicos que han escrito al respecto en contextos y momentos históricos diferentes. Así mismo, busco explorar cómo deviene el colono en campesino en regiones de frontera interna ${ }^{1}$, en oposición a zonas periféricas en las que se vive el conflicto armado y hay cultivos declarados de uso ilícito. Una vez establecida esta contraposición central, me pregunto cómo se manifiesta la representación del colono campesino y/o campesino colono en regiones de frontera abierta ${ }^{2}$, en donde dichas denominaciones parecen no reconocerle un arraigo a quien así se nombra, al considerarlo en permanente movimiento. Además, me cuestiono por cómo se profundiza esta situación cuando a estos sujetos se los criminaliza y estigmatiza al identificarlos como colonos cocaleros o cultivadores de una planta que, como la coca, es declarada ilegal. En suma, busco examinar la contingencia del uso de la categoría colono y de las diferentes imágenes asociadas a esta. Como se mostrará, no es posible establecer una definición uniforme del término, pues en la mayoría de los casos se caracteriza por su imagen ambivalente, producto de los debates sobre su representación según contextos y relaciones de poder determinados.

Argumento que, como una solución alterna a la reforma agraria en el país, el peso histórico de la colonización del oriente colombiano — piedemonte de $\mathrm{Pu}$ tumayo, Caquetá y Guaviare y el departamento del Meta- ha llevado a que la categoría de colono sea excluyente para aquellos a quienes se les adscribe porque los despoja de su condición de campesinos. La desposesión y la exclusión se profundizan cuando se trata de cultivadores de coca y cuando la categoría colono se sustituye por la de colono cocalero, lo cual no solo lo criminaliza y estigmatiza sino también niega su identidad como campesino y, de esta manera, previene su constitución como tal. En este contexto, durante varias décadas los cultivadores de coca han reivindicado su reconocimiento como campesinos cocaleros y, más recientemente, como campesinos — sin adjetivos-y sujetos políticos con

1 Es decir, territorios de colonización que continúan insertados en medio de zonas con estructuras más consolidadas.

2 Zonas de colonización del sur y oriente del país, en donde existen diversos actores armados no estatales que ejercen control del territorio y autoridad. 
derechos diferenciados. Vale la pena tener presente, como señala Laclau (1990), que "la constitución de una identidad social es un acto de poder y que la identidad como tal es poder” (31, cursivas en el original).

El artículo se desarrolla de la siguiente manera: en primer lugar, analizo qué significa la categoría de colono a mediados del XIX, tanto en la frontera interna, donde se destaca la colonización antioqueña, como en la frontera abierta de los denominados territorios nacionales; allí resalto las diferencias de representación del colono en cada una de estas regiones. En segundo lugar, analizo la colonización de la Amazonia occidental a mediados del siglo XX durante el periodo de La Violencia, momento en el cual crece el influjo de colonos a esta región como resultado de la decisión del Gobierno de incentivar la colonización para no llevar a cabo una reforma agraria. En tercer lugar, trato el asunto de la llamada “colonización armada” —-denominada así por investigadores durante los años setenta y ochenta - para considerar hasta qué punto el uso de las armas fue la característica central en contraposición con la llamada colonización espontánea y dirigida; con ello, llamo la atención a los cuestionamientos de varios autores a algunas de estas caracterizaciones. En cuarto lugar, analizo el contenido y las resignificaciones de las categorías colono campesino, campesino colono, colono cocalero y campesino cocalero, y la demanda de quienes así han sido llamados para ser reconocidos como campesinos. En cada apartado me referiré indistintamente a los departamentos de Putumayo, Caquetá, Guaviare y Meta con el fin de establecer comparaciones cuando lo considere pertinente.

\section{Colonos de frontera interna y de frontera abierta: tierras baldías y territorios nacionales}

Es indefectible iniciar esta discusión a partir de la definición de campesino que presenta Catherine LeGrand en su estudio seminal sobre la colonización en Colombia entre 1850 y 1950. Después de aclarar que se trata de un término muy debatido, LeGrand lo define como los "pequeños cultivadores rurales que dependen de la mano de obra familiar para producir lo que consumen” ([1986] 2017, 10). Para ella, este término "incluye a los aparceros, arrendatarios, pequeños propietarios y colonos de frontera” (10). Aparecen aquí los llamados colonos como una categoría que los pequeños propietarios y arrendatarios, aparceros o 
“artesanos de la montaña” adoptan cuando se movilizan para invadir o colonizar baldíos en "tierras medias o calientes”. Para Tovar (1995), este "desbordamiento" de habitantes de los altiplanos andinos sobre las vertientes, que se intensificó a partir de 1870, "fue uno de los fenómenos sociales más importantes del siglo XIX” (33). Sobre las características de los colonos de frontera, LeGrand ([1986] 2017) comenta que, "si en ciertas áreas predominaban los colonos negros o indios, la mayoría eran de ancestro mixto hispano-indio, reflejo de la composición primordialmente mestiza de la población colombiana” (43). Desde una perspectiva racial, el colono es definido como mestizo antes que como blanco, mestizaje que se asimiló con el pueblo en una sociedad jerarquizada donde el blanco ocupó un lugar privilegiado durante la Colonia como descendiente español. Más adelante profundizaré en este tema racial y de clase.

LeGrand destaca cómo estos colonos no solo cultivaban productos para consumo interno, sino también cacao, café y otros de exportación. Además, la autora anota que fueron reconocidos como colonos independientes por cuanto no formaban parte de las grandes colonias o poblaciones que se fundaron en Antioquia entre 1860 y 1890. Finalmente, señala que "los cultivadores de baldíos fueron el único grupo campesino de Colombia cuyos derechos obtuvieron una definición legal explícita a fines del siglo XIX y comienzos del XX” ([1986] 2017, 34); este reconocimiento jurídico fue sostenido tanto por Gobiernos liberales como conservadores, teniendo en cuenta que "legalmente eran colonos aquellos y solo aquellos individuos que cultivaban la tierra o criaban ganado en tierras baldías sin disponer de un título escrito al territorio explotado" (40), sin importar su extensión. Tovar (1995) considera que "la lucha por la delimitación y el reconocimiento de la propiedad se tornó en el núcleo de los problemas agrarios del siglo XIX" (66).

Para el caso de la colonización de Sumapaz, González y Marulanda (1990) señalan que, en el marco del Decreto 1110 de 1928³ (Presidencia de la República 1928), los arrendatarios de las haciendas se negaron a pagar arriendo y "se declararon colonos alegando que las tierras que cultivaban habían sido usurpadas a la nación” (33). Después de movilizaciones y tomas de tierras inexplotadas, "solicitaron la adjudicación en calidad de colonos de las tierras que habían ocupado”, y denunciaron como baldíos extensos territorios pertenecientes a diferentes

3 Este decreto adoptó la política de colonización de baldíos como solución al enfrentamiento del modelo hacendatario y el modelo campesino para bajar la presión campesina sobre las haciendas; se destinaron varias zonas del territorio nacional para la colonización y "en el departamento del Tolima [el Gobierno] alinderó para este fin algunos terrenos ubicados en el municipio de Cunday e Icononzo, sobre los cuales se constituyó la 'Colonia Agrícola de Sumpaz"” (González y Marulanda 1990, 30), a la que me referiré más adelante. 
haciendas de Pandi, Cunday e Icononzo. En uno y otro caso, empieza a hacerse evidente que la titulación de las tierras baldías - o la ausencia de esta- determinaba la condición de colono, pues, una vez titulados sus predios, se constituían en campesinos y, sobre todo, dejaban de ser considerados poseedores ilegales para entrar a ser parte del orden legal nacional ${ }^{4}$.

Así, como lo señala Yie (2018), con el tiempo el término colono fue "subsumido bajo el de campesino” (66), aunque esto solo se cumplió para ciertas colonizaciones de la primera mitad del siglo XX en Colombia, como la colonización antioqueña, que dio lugar a la representación de un colono "laborioso, resuelto e incluso heroico cuyos esfuerzos por abrir nuevas tierras contribuían a la causa del desarrollo nacional” (LeGrand [1986] 2017, 37) ${ }^{5}$. Sin embargo, para la colonización de la segunda mitad del siglo XX, que amplió la frontera agrícola hacia los Llanos y la Amazonia occidental del país, la condición de ilegalidad del colono campesino por falta de titulación de las tierras no solo ha sido una constante, sino una limitante para el asentamiento e integración del colono al orden nacional como campesino con derechos.

La colonización es constitutiva del proyecto de integración territorial y social de la nación. El establecimiento de la soberanía del Estado nación sobre las regiones de frontera que aparecían excluidas del orden central se convirtió desde entonces en una metanarrativa predominante del imaginario de la nación colombiana (Ramírez 2015). En este orden de ideas, en 1843 se constituyeron los territorios nacionales, que coincidían con las fronteras abiertas del oriente del país, territorios poco conocidos y poblados, pero "que [la nación] valora como un potencial” (Serje 2005, 112). Estos territorios fueron administrados directamente por el Gobierno central y, en documentos de archivo del Departamento Administrativo de Intendencias y Comisarías (Dainco), creado en 1975, sus gobernantes son representados como “débiles administrativamente”, por lo que se planteaba permanentemente la necesidad de programas de capacitación "para que estos tengan un papel más importante en la dirección de sus destinos” (Dainco 1982, 7). Así, implícitamente se legitimaba su subordinación a la intervención del Gobierno central con el ánimo de integrar estos territorios a la nación para que pudieran brindar recursos y posibilidades para el resto del país. Se constata

"Al menos el 44\% de las tierras adjudicadas en el siglo XIX se localizaban en la región antioqueña, un $15 \%$ en el Tolima, un $16 \%$ en los Llanos y el $25 \%$ restantes en las otras regiones de Colombia" (Tovar 1995, 66).

5 Vale la pena aclarar, como lo hacen Arias y Bolívar $(2006,63)$, que la colonización antioqueña ocultó otras colonizaciones que se presentaron en el siglo XIX, especialmente la boyacense. Para el presente caso, la colonización antioqueña es el referente y, por tanto, me detengo en ella. 
lo que señala Serje (2005) para el “revés de la nación”, en cuanto a que estos territorios nacionales "deben plegarse y convertirse en instrumento de los designios y necesidades del Estado [...] siempre en función del punto de vista de los requerimientos y aspiraciones de la llamada sociedad mayor, de las ventajas que para esta pueden representar" (138). Estos territorios fueron concebidos como terra nullius o tierras legalmente designadas como vacías, en consonancia con una perspectiva colonial que desconoce la propiedad de hecho de los pueblos nativos, así como sus formas de propiedad y, por consiguiente, los considera potencialmente colonizables. No obstante, el Estado delegó en los misioneros sus funciones de gobierno a través del concordato de 1887, para que los indígenas “salvajes” fueran “catequizados y civilizados”. Así, aunque se reconocía implícitamente su presencia, no ocurría lo mismo con el respeto de sus derechos; incluso llegaron a ser declarados “menores de edad” (Ley 89 de 1890).

Es así como todo el gran Territorio de Caquetá ${ }^{2}$ era considerado baldío, “con excepción del corregimiento de Sibundoy [en el Alto Putumayo], compuesto por 'tierras de resguardo'” (Gómez 2010, 196). Para el caso de Putumayo, llegaron colonos indígenas desde 1884, como resultado de los procesos de desintegración de los resguardos de Nariño, provenientes del municipio de La Cruz y otros a sus alrededores (Chaves 1945). En esta primera ola también llegaron colonos campesinos no solo desde Nariño, Cauca y Huila, tal como lo documenta Milcíades Chaves (1945), quien sostiene que "esta primera colonización fue realizada por el hambre, sin ningún interés por parte del Estado o entidades oficiales” (580). Chaves denuncia que "los colonos han sido abandonados a su propia suerte" y los describe como una "clase desposeída y harapienta” y "sin ningún capital” (580 y 585). Para el autor, la colonización era "una solución para una masa desarraigada” (581) que había perdido su tierra, ya fuera por el avance del latifundio o por el proceso de microminifundización de sus parcelas. Chaves reconoce una segunda etapa de la colonización en Putumayo coincidente con el conflicto con el Perú en 1932, evento que llevó a la apertura de vías de acceso e hizo que algunos combatientes se quedaran a vivir en la región; adicionalmente, insiste en que "el gobierno aún sigue de espaldas ante estos dolorosos problemas” (587).

Aquí vale la pena señalar que el ejercicio de la soberanía en estas zonas de frontera llevó a que el ejército colombiano estableciera colonias militares, como fueron los casos de La Pedrera en el Amazonas en 1911 y de Puerto Ospina 
y Caucayá sobre el río Putumayo, así como el de La Tagua. Lo anterior se tradujo en el inicio del primer proyecto de colonización militar que llevó a la apertura de la trocha Caucayá-La Tagua y la consecuente instalación de la principal guarnición del Putumayo en Caucayá, ejercicios que culminaron con el mencionado conflicto con el Perú (Culma 2013, 27-28).

Así mismo, para el caso del Caquetá, Alejandra Ciro (2008) señala que sus vínculos con el Huila "eran de origen prehispánico y, por lo menos desde el siglo XIX, se habían presentado procesos migratorios de colonos provenientes de este departamento hacia el piedemonte” (56). LeGrand ([1986] 2017) también se refiere al desplazamiento de indios "montaña arriba o hacia el sur a las selvas de Caquetá y Putumayo” (42) en las primeras décadas del siglo XX. Esta colonización temprana, tanto por parte de indígenas como de campesinos, nos lleva a la necesidad de contextualizar históricamente la designación de "blanco”, “indígena”, “indio" e incluso de "negro", como lo propone Gómez (2010), para que "la semántica sea entendida cabalmente (y, sobre todo, con sus respectivas cargas racistas y peyorativas)” (190). En mi opinión, se trata de una reflexión que debe extenderse a la categoría de colono, cuya construcción histórica no representa monolíticamente al blanco "frente al indio o frente al negro", ni tampoco "a la sociedad civilizadora” como lo supone Serje $(2005,204)$. Esto último ocurre no solo porque los colonos sean representados como "mestizos", sino porque, como dice Chaves, “sus desventajas son numerosas”, pues están sujetos a "una subalimentación, a un estancamiento en la técnica y a una pobreza sin remedio” (Chaves 1945, 581), lo cual riñe con la idea de ser promotores del progreso. Estaríamos así frente a una manifestación de lo que Bhabba ([1994] 2007, 92) ha llamado la ambivalencia del estereotipo, al cuestionar la “fijeza’ en la construcción de la otredad”, que en este caso se traduciría en la construcción histórica y espacial de la categoría.

Por otra parte, en 1885 también aparecen “forasteros” en el Valle de Sibundoy, como designaban los misioneros a "radicales enemigos declarados del Gobierno”, así como a otros "blancos” antiguos caucheros, quineros y comerciantes que se quedaron a vivir en estas regiones de selva, y que de hecho conformaron pueblos como el de Molina, lo que conllevó la segregación de una porción de terreno de Sibundoy en el Alto Putumayo para ser constituido (Gómez 2010, 191). Estos “blancos” no cumplían con las características adscritas a los colonos mestizos que emigraban a buscar tierras en el oriente del país, lo cual nos introduce a la diferenciación de clase social que se establece en las zonas de colonización, como se analizará más adelante.

A principios del siglo XX, aunque ser colono empieza a ser equiparado a ser "blanco", esta categoría racial contiene elementos culturales y morales, pues algunos “colonos indios”, que no se autorreconocían como tales, actuaban frente 
a sus "paisanos" indígenas como si quisieran ser identificados como "blancos", pero sobre todo como "no-salvajes”. Esta última condición fue enfatizada por los misioneros, quienes agregaron su calidad "civilizadora” a los colonos que llegaron a estos territorios nacionales desde otros lugares, invitados a fundar "pueblos de blancos” cerca de las tierras indígenas como una estrategia tanto para “civilizar” como para integrar a sus pobladores. En consecuencia:

El Prefecto Apostólico partiendo del principio que el punto de apoyo más importante para la evangelización era la colonización, presentó al Congreso Nacional un proyecto de ley [...] el cual se conoce como La Ley 52 de 1913 mediante la cual se dio vida a la Junta de Inmigración y Colonización [en complemento a la ya creada Junta de Baldíos] integrada por el gobernador del Departamento de Nariño, el Prefecto Apostólico y un representante del Ministerio de Gobierno. La principal función de la junta fue atender a la colonización de los Territorios Nacionales del Caquetá y Putumayo con individuos o familias nacionales o extranjeras y en general toda su gestión y ejecución. (Casas 2001, 420)

Tal es el caso del pueblo de Alvernia, fundado en 1916 en el noreste de Mocoa (Putumayo) con inmigrantes de Antioquia que llegaron después de que emisarios del prefecto apostólico recorrieran pueblos como La Ceja, Mesopotamia y Sonsón, entre otros, con el fin de invitar a sus pobladores a colonizar Putumayo y Caquetá, con lo que confirmaron que "lo antioqueño obedecía a los valores de una vida moderna, a la vez moral y civilizada” (Arias Vanegas 2007, 110). El prefecto escogió antioqueños por tratarse de "esta raza viril y pujante cuyas dotes de trabajo y energías indomables son proverbiales en Colombia” (Charry 1991, 62-63), una raza que aseguraría el éxito de la colonización, tal como había sucedido con la colonización de Caldas, Risaralda, Quindío, norte del Valle y norte de Tolima7 ${ }^{7}$ Sin embargo, los colonos antioqueños no se adaptaron a las condiciones de este territorio selvático sin buenas vías de comunicación y sin productos comerciales exitosos, como el caso del café en su región de procedencia ${ }^{8}$.

La idea del colono antioqueño como miembro de una "raza pujante" se reitera en este contexto y parece constituirse en una categoría racial, que representaba a los antioqueños como una "raza superior" (Melo 2013). En su estudio

7 Sobre las características de la colonización del norte, centro y sur del Tolima en el siglo XIX, véase Tovar (1995).

Como lo señalan Arias Vanegas y Bolívar $(2006,63)$ en su trabajo sobre Montenegro (Quindío), la producción y comercialización del café a lo largo del siglo XX se representaron como propiciadoras tanto de la civilización a través de la colonización como del establecimiento de "una 'buena' cultura campesina". Además, los autores afirman que "la construcción de una memoria colonizadora es uno de los fundamentos de la identidad colectiva que se teje en el Eje Cafetero" (66). 
sobre los grupos poblacionales del municipio de Vistahermosa en el Meta, Vásquez $(2006,174)$ también hace referencia a "la 'superioridad' de la identidad paisa”, la cual relaciona "con el progreso del país, con la astucia y el respeto por los valores”, y resalta cómo "se identifica como 'natural' a su raza” y cómo se supone heredada “de generación en generación”. En contraposición, se refiere a la identidad adscrita a aquellos otros colonos que llegaron desplazados de Sumapaz y el sur del Tolima a mediados del siglo XX, y que son representados como "bandoleros" con "inferioridad moral” y con "tendencia "natural” a lo ilegal - a ellos me referiré más adelante-.

Al respecto, Yie (2018) sostiene que, "aunque el término colono no constituía una categoría racial, en la práctica parece haber funcionado como tal” (69), al considerar que se encuentra entre el indio y el negro, según lo sugiere Serje (2005). Algo similar ocurre con la categoría mestizo que tiene inmersa "una ambigüedad étnica y racial”, como lo señala Margarita Chaves (1998, 283), y que sin duda servía para identificar a los pequeños campesinos andinos que llegaban como colonos campesinos a la Amazonia occidental. Sin embargo, habría que considerar si esa denominación también identificaba a los colonos "blancos” antioqueños, teniendo en cuenta "la pureza de raza" como un elemento del imaginario antioqueño, que en algunos casos los hacía considerarse "descendientes de españoles” y, en otros, “dotad[os] de lo mejor del mestizaje”, así como miembros de “una cultura singular” (Aristizábal 2016, 3).

Cabe preguntarnos entonces si, en lugar de raza, estamos frente a la emergencia de una identidad colectiva regional que diferenciaba a los antioqueños de otros grupos de colonos mestizos o "blancos” del país. Al respecto, Arias Vanegas (2007) resalta que en el siglo XIX “el tipo antioqueño era descrito especialmente como mestizo blanco” (108), se exaltaba su belleza física y se establecía una conexión con su “constitución social y moral”. Por otra parte, para Appelbaum (2003, 33-35) esta "raza” era resultado de la consolidación de una fuerte identidad regional colectiva por parte de los antioqueños, que los unió bajo una comunidad imaginada que consideraba a los foráneos como el otro contra el que se unían y contra el que medían la superioridad de su raza. De esta manera, los antioqueños emergieron como un tipo regional y racial en el siglo XIX, cuando "las diferencias regionales no eran pensadas por fuera del racialismo" y "se constituyó en el proyecto regional más fuerte de la segunda mitad del siglo XIX” (Arias Vanegas 2007, 102 y 109), en oposición a los habitantes del altiplano. Aquí quiero resaltar

9 Como lo evidencia Arias Vanegas (2007), al referirse a la construcción de nación en el siglo XIX, esta "se funda en una imagen de homogeneidad que genera patrones jerárquicos de incorporación [...] Los Santanderes y el altiplano cundiboyacense y contadas ciudades como Popayán y Cartagena aparecían provistas de un glorioso pasado; mientras que, en el otro 
que, en la racialización de la categoría colono se hacen notorias las diferencias en términos regionales o de lugar de procedencia, así como en términos de clase. Dejo abierta la pregunta sobre cómo se asume en este siglo esta condición de colonos mestizos en su identificación como campesinos y no como indígenas.

Por su parte, en el Valle de Sibundoy, la misión reglamentó la fundación del pueblo de Sucre mediante la Ley 69 de 1914 y estableció "un término de 90 días para que los ocupantes de los terrenos del Valle exhibieran ante la Junta de Baldíos los títulos de dominio, con los cuales pudiese[n] comprobar su condición de "colonos cultivadores"; la Junta "se encargaría de calificar los títulos presentados y decidiría sobre sus derechos” (Charry 1991, 72). Aquí sobresale la categoría de colono cultivador para aquel que podría acceder a un título de cultivador sobre un lote de terreno baldío, frente a la de colono a secas, ocupante de tierras baldías de la nación.

Las dos categorías, colono y cultivador, fueron utilizadas en leyes de finales del siglo XIX para referirse a los posibles reclamantes de tierra (Yie 2018, 65). No obstante, eran estos colonos y cultivadores quienes disputaban el derecho a la posesión y a la propiedad de tierras baldías con empresarios y tenedores interesados en fundar empresas agrícolas, ganaderas o de extracción (Tovar 1995, 124). Por otra parte, este requisito de demostrar su condición de cultivador para reclamar su derecho a una pequeña parcela nos podría llevar a pensar que, por cultivar la tierra, estos colonos cultivadores se diferenciarían de aquel colono que no se asentaba del todo y seguía avanzando en la ampliación de la frontera agrícola.

En el caso de la selva del Guaviare, Del Cairo $(1998,78)$ explica el significado que cobra para el colono "fundarse" en este territorio, lo cual conlleva “civilizar la tierra” y ya no "civilizar al indio”. Esta "fundación” se constituye en "parte de su identidad”, de manera que "la finca se erige como lugar civilizado y, por tanto, existen espacios salvajes que actúan como referentes de contrastación: el espacio salvaje lo marca la tierra de los indígenas y los indígenas en sí mismos" (85). En este orden de ideas, para Ferro y Uribe (2004) "transformar la selva en tierra habitable” (121) es lo que da identidad y sentido de pertenencia al colono. Entonces, en estos colonos sobresale su condición de campesinos que hacen cultivable la tierra siguiendo parámetros andinos (Ciro 2008; Leal 1995), que en este contexto se consideran "productos civilizadores" (Acero s. f., 217) frente a los amazónicos, muchas veces sin tener éxito - lo cual los lleva a vender sus mejoras-. En este caso, como en Meta y Caquetá, transformar la finca en pastos para ganado se convierte en uno de los objetivos para lograr la permanencia en su

extremo, las regiones de frontera, los valles interandinos y las zonas selváticas estaban antecedidos de historias de conquistas fallidas y de pueblos belicosos" (8-9). 
fundo por considerar que la agricultura puede ser insuficiente para garantizar su sustento (Acero s. f.; Ciro 2008). Culma Vargas (2013) plantea que, para el caso de esta región de la Amazonia occidental, se debe hablar de frontera agropecuaria y no solamente de frontera agrícola, por cuanto "los procesos de integración económica y social de estos territorios se ha basado muchas veces en procesos de 'ganaderización'” (23).

\section{Colonización dirigida y colonización espontánea o forzada}

La colonización dirigida promovida por el Estado, además de ser una estrategia que sustituyó la redistribución de la tierra dentro de la frontera agraria (Fajardo 2018; Martínez 2017; Salgado 2012; Torres 2020; entre otros), "se confunde con la historia y los ritmos de la violencia”, en palabras de Gonzalo Sánchez Gómez $(1988,35)$. Fue así como poco después del 9 de abril de 1948 se creó el Instituto de Parcelaciones, Colonización y Defensa Forestal, cuyo fin principal era incrementar la producción agrícola, misión que se modificó en 1952 para impulsar la colonización del valle del Magdalena. En 1953 se creó el Instituto de Colonización e Inmigración, que priorizó la infraestructura y asistencia a ganaderos y agricultores ya establecidos. Esta entidad se liquidó en 1956, cuando sus labores relacionadas con las colonizaciones en el país se trasladaron a la Caja de Crédito Agrario Industrial y Minero. Para mayor cobertura de este programa, el Congreso aprobó la Ley 20 de 1959 conforme a la cual las cajas y secciones de ahorros de los bancos establecidas en el país debían invertir el $10 \%$ de sus depósitos de ahorros en la ejecución de programas de parcelación y colonización de tierras (Barrera 1963).

A finales de 1958, bajo la dirección de la Caja Agraria, se iniciaron programas de colonización dirigida en Ariari (Meta) — que se constituyó en el centro piloto-, Sarare (Norte de Santander), Lebrija (Santander), Galilea (Sumapaz), Doncello y Belén (Caquetá), en el marco de los planes de la Oficina Nacional de Rehabilitación creada por el Frente Nacional después del periodo de La Violencia (Sánchez Gómez 1988, 36). Vale la pena anotar que el historiador Robert Karl (2017) se refiere a esta oficina como la entidad encargada de la reparación después de la "paz criolla" negociada entre liberales y conservadores que dio lugar al Frente Nacional. Por su parte, Brucher ([1968] 1974, 229) atribuye el lento progreso y la menor expansión de la tierra colonizadora en el Putumayo a la falta de proyectos de colonización. 
Muchos de los proyectos de colonización dirigida fracasaron, como lo constató Torres (2020) para el caso del Ariari en Canaguaro, al no encontrar ningún colono que hubiera recibido tierra o participado en los primeros proyectos de colonización dirigida para ser entrevistado. Al contrario, solo se presentaron aquellos que llegaron por cuenta propia, es decir, los denominados colonos espontáneos, concepto que empieza a ser utilizado en la literatura desde comienzos del siglo XIX para referirse a la migración de familias del interior del país a territorios de colonización (Tovar 1995). Esta categoría es criticada por autores como Serrano (1994) y Salgado (2012), quienes coinciden en su rechazo del carácter “espontáneo” de la migración, por cuanto consideran que oculta las causas sociales y económicas que obligan a los campesinos a desplazarse. La categoría de colono espontáneo conlleva la idea de que colonizar es una aventura, algo fortuito y voluntario, al asumir que se migra para buscar nuevas oportunidades y mejor suerte, lo que pierde de vista las causas estructurales que dan lugar a la colonización, tales como la concentración de tierras y la microminifundización antes anotadas. En 1982, Ernesto Guhl $(1982,98)$ afirmaba que "no hay colonización espontánea en la selva pluvial colombiana” y, en consonancia con Milcíades Chaves, sostenía que:

[Los colonos] no son ni aventureros ni conquistadores, sino unos pobres desplazados y hambrientos. Son un sobrante del potencial humano del país, que huye desesperadamente de un orden social y económico establecido en el interior andino, que solo les ofrece muy precarias condiciones de vida y ningún porvenir; y donde la subalimentación, la subocupación, la subeducación, en una palabra, el subdesarrollo, se ha convertido en una institución y una forma de vida para una gran parte de la sociedad. (Guhl 1982, 98)

A partir de una revisión histórica de la política agraria y de colonización campesina en la región amazónica, Salgado (2012) constata una dinámica sucesiva de expropiación territorial del campesinado por parte de los empresarios agrarios, que no solo han usurpado sino legalizado los predios despojados con la aquiescencia del Estado. Por esta razón, el autor propone el término de colonización forzada para describir estos procesos de colonización a los que se ven obligados los campesinos y que han dado lugar a las grandes diásporas. Tal es el caso de La Violencia de los años cincuenta que conllevó la

expropiación de 400000 propietarios del sector rural, fundamentalmente pequeños y medianos campesinos [y que dio lugar a un] formidable proceso de migración de la población agraria cuando dos millones de personas tienen que abandonar su tierra de origen. (Jaramillo, Mora y Cubides 1986, 12) 
Es así como la mayor afluencia de colonos al Putumayo, Caquetá y Guaviare se dio durante esta época de La Violencia. La mayoría de ellos provenientes de Nariño y Cauca, en el caso de Putumayo; del Huila, en el caso de Caquetá; y de Cundinamarca, Boyacá y los Llanos Orientales, en el caso de Guaviare. Como lo señala Claudia Leal (1995), la colonización "ha sido también una de las formas de reproducción de los campesinos como grupo social marginal en Colombia” (14). Acero (s. f.) enfatiza que se trata de personas y familias "que se resisten a su descomposición como campesinos y ven en la colonización una salida a su situación” (216).

En ese momento, ser colonos campesinos era una condición identitaria en tanto salían a colonizar el piedemonte andino amazónico, un medio ajeno a su lugar de origen, en busca de tierras para asentarse y establecer una economía agropecuaria. La condición de campesinos de los colonos que llegaron al piedemonte amazónico la resalta Laura Rincón (2018) en la revisión que hace de su representación en la prensa nacional entre 1948 y 1991, por lo cual se refiere al campesino-colono antes que al colono-campesino. Aunque la autora lo justifica por tratarse de cómo se autodefinen hoy los campesinos del Área de Manejo Especial para La Macarena, considero que el ser colonos dominaba en el inicio de la colonización y, como se verá más adelante, cuando se consolidó la colonización fue que se reconocieron como campesinos-colonos.

Una mujer del Valle del Guamués en Putumayo, proveniente de Nariño, recuerda: “desde el principio me encantó estas tierras a pesar de las fieras como culebras, tigres y bichos como mosquitos y arenillas que molestaban mucho... era una tierra fértil donde lo que sembramos producía, así que, aunque no teníamos plata, teníamos qué comer de sobra” (entrevista en El Placer, 2010). Su hijo relata: "unidos nos dedicamos a sembrar arroz, plátano, chiro, maíz, fríjol, maní. Mi madre se dedicó a la huerta casera y los animales como cuyes, gallinas y cerdos” (entrevista en El Placer, 2010). Mientras la colonización caqueteña huilense enfatizó la ganadería como renglón principal, la putumayense, la nariñense y la pastusa se concentraron en la agricultura y en especies menores como los cerdos. Para el caso del Alto Guaviare, entre 1953 y 1959 también aumentó la llegada de colonos, con el cacao y los cerdos como renglones centrales de la producción. "Los colonos de estos años tenían tradición agrícola, llegaban escapando de la muerte como a una tierra de promisión y, sobre todo, venían a establecerse con sus familias” (Molano 1987, 34).

El Instituto Colombiano de la Reforma Agraria (Incora) fue creado por la Ley 135 de 1961 para "administrar a nombre del Estado las tierras baldías de propiedad nacional, adjudicarlas o constituir reservas y adelantar colonizaciones sobre ellas” (cap. 2, art. 3, inciso a). Para Rincón (2018), con su creación se 
inaugura en la prensa nacional el periodo al que denomina de "esperanzas y promesas” (1961-1972), cuando poseer un pedazo de tierra en Caquetá era una posibilidad. En 1962, el Incora asumió los programas de colonización dirigida; inició con el proyecto Caquetá 1 (1963-1971) y continuó con el proyecto Meta 1 (1964-1974) $)^{10}$, para promover con mayor ahínco la ganadería que ya estaba instalada allí y, con ello, impulsar el desmonte de la selva y la consecuente potrerización como indicador de que "el progreso venía con la praderización y la utopía era la ganadería” (Ciro 2008, 29). En Caquetá surgió la gran hacienda Larandia con 30000 ha de extensión dedicadas a ganadería intensiva como principal renglón de producción.

Para Brucher (1974), la colonización estatal había “comenzado tarde y, por ende, se ha[bía] quedado a la zaga — en forma notoria si no definitiva-comparada con la modalidad de ocupación de tierra llevada a cabo realmente por 'colonos espontáneos”’ (240). El autor señala que en los años setenta los colonos espontáneos privilegiaron la explotación de potreros para la ganadería y comenta que "esta rama de la economía no solamente es más productiva y duradera en los suelos de la selva virgen, sino que además obliga a los colonos a volverse sedentarios, a convertirse en campesinos” (236). En esta afirmación Brucher reitera que el paso de ser colono a ser campesino implica asentarse definitivamente; por consiguiente, desde entonces se privilegia la ganadería como renglón productivo, lo cual sigue teniendo vigencia hoy en el caso del Caquetá, el Guaviare y el Meta. No obstante, los costos de la actividad ganadera son altos e influyen en la diferenciación social y de clase.

En su trabajo sobre Estado, burocracias y colonos en el Caquetá, Martínez (2017) encuentra evidencia de la distinción entre la representación del "colono espontáneo" como "aventurero, dispuesto a sortear toda clase de vicisitudes” y, en contravía, el "colono dirigido" como aquel "incapaz de valerse por sí mismo" y dependiente del Estado (18). Se exalta al colono espontáneo porque se quedó a trabajar la tierra, pero sobre todo por "hacer patria”, lo que responde al imaginario de que colonizar también implicaba contribuir a ejercer la soberanía del Estado con su presencia en remotas zonas de frontera.

Por su parte, Rincón (2018) se refiere a "los valientes hacedores de patria” en el Caquetá, como los denomina la prensa nacional, en dos momentos: entre 1948 y 1961, cuando la región amazónica se convirtió en refugio de La Violencia,

10 María Clara Torres $(2020,77)$ señala que el Incora se benefició del Programa de Rehabilitación (1958-1962) por traer consigo lecciones para aplicar y constituirse en proyecto piloto; sin embargo, se diferenció de este en cuanto que el Incora vinculó a la población desposeída y desplazada que vivía en las zonas de colonización y enfatizó los proyectos de "eficiencia", "racionalidad", "productividad y desarrollo". 
y entre 1973 y 1980, cuando los colonos se hicieron visibles con sus "rostros y voces”. Tal es la idea que se deduce de la descripción que hizo El Espectador en 1960 con respecto al proyecto de colonización dirigida del Sarare promovido por la Caja Agraria: "Aventureros heroicos que descuajan la selva en lugares perdidos en el mapa, con la sola compañía de las mulas y de los perros y a veces sin ella” (citado en Martínez 2017, 124). Tumbar la selva se asociaba no solo a “civilizar”, sino a recuperar los territorios “abandonados” por el Estado, territorios salvajes a los que se enfrentaba un colono cuya "vida depend[ía] de una lucha titánica contra la selva y la topografía que siempre le resulta infructuosa y de la esperanza de poder contar con la 'ciudad letrada' que ni lo reconoce, ni lo adopta” (Serje 2005 , 204). Sin embargo, una vez logra fundarse, el colono no consigue el reconocimiento del Estado como ciudadano pleno, pues hacer patria en las fronteras no conlleva tener derechos.

\section{Colonización armada - colonización organizada}

La llamada colonización armada se remonta al movimiento agrarista de los años treinta y cuarenta del siglo XX, que tuvo lugar en Tolima, Cundinamarca - específicamente en la región del Tequendama- y Sumapaz. En estos lugares se formaron ligas y sindicatos agrarios cuyos campesinos se levantaron contra las haciendas y su condición de arrendatarios, se tomaron tierras y fundaron colonias agrícolas ${ }^{11}$. Lo anterior desembocó más adelante en la promulgación de la Ley 200 de 1936 (Molano 1987, 37-38), que aceptó la gran propiedad y evadió la reforma agraria. Estas ligas y sindicatos agrarios "se constituyeron en el principal mecanismo de resistencia de los campesinos frente a los permanentes intentos de los empresarios agrarios para desalojarlos y apropiarse de sus territorios” (Salgado 2012, 74).

11 Como se anotó, en 1928 se conformó en Sumapaz la primera colonia agrícola en el marco del Decreto 1110 de 1928. Para Fajardo (2018), esta figura fue la predecesora de las zonas de reserva campesina. Por su parte, LeGrand ve las colonias agrícolas como anticipadoras de las repúblicas independientes que emergieron más tarde en Sumpaz y otros lugares durante La Violencia (LeGrand en Salgado 2012, 74). Londoño $(2011,206)$ anota que los hacendados vieron este decreto como promotor de la agitación rural y de la infiltración comunista entre los campesinos. 
En este orden de ideas, Alonso (2020), en su estudio sobre periódicos campesinos del siglo XX, señala que en el periódico Claridad ${ }^{12}$ la figura del colono es central y se presenta como "aquel que debe conquistar la nación, el verdadero dueño y defensor de la tierra y quien se agita en todo el país para hacer valer sus derechos" (Claridad, citado por Alonso 2020, 39). Además, enfatiza que "se le representa como un sujeto en distinción que tiene más capacidad que el campesinado en general" (Alonso 2020, 39-40). Esta imagen combativa que destaca su capacidad de movilización hace que, desde esta época, los colonos de Sumapaz fueran tildados de subversivos, radicales y violentos, con lo cual empieza una estigmatización (Londoño 2011) que los ha acompañado hasta el día de hoy ${ }^{13}$.

El asesinato de Gaitán en 1948, cuyas bases estaban conformadas por estos campesinos liberales, hizo que este movimiento campesino se levantara y fuera atacado y perseguido por los chulavitas o conservadores defensores de los terratenientes, por lo que tuvieron que desplazarse. Para Fajardo (2018), este evento hizo evidente la derrota del reformismo liberal que en la década de los treinta buscó regular la propiedad, modernizar el sector agrario y reconocer las organizaciones sociales campesinas. Así, en un primer momento, huyeron al monte $\mathrm{y}$ "se armaron con las pocas y rústicas armas que poseían e iniciaron, sobre la base de su debilidad, un movimiento defensivo que aumentaba día a día” (Molano 1987, 39). Se trata del bandolerismo social, en palabras de Sánchez Gómez y Meertens (1983), o de campesinos armados, en su mayoría de filiación liberal. Estos campesinos se defendieron de los atropellos a sus familias y, con el tiempo, se convirtieron en grupos de autodefensa campesina, sobre todo en Tolima y Sumapaz, donde tenían conexiones con el Partido Comunista. Estos grupos posteriormente devinieron en guerrillas revolucionarias ${ }^{14}$.

En 1953 los militares al mando del general Gustavo Rojas Pinilla se tomaron el poder, se detuvo la guerra civil y se decretó la amnistía con los guerrilleros que luchaban en el llano y el sur del Tolima (Molano 1988, 94). No obstante, en 1955 se retomó la guerra cuando el mismo Rojas declaró ilegal al Partido Comunista, atacó Sumapaz y se tomó Villarrica (oriente de Tolima) después de un

12 Órgano de difusión del Partido Agrario Nacional (PAN), publicado entre 1928 y 1937 y dirigido al movimiento de colonos de Sumapaz.

13 Se llegó a plantear si el campesino podía ser considerado un ciudadano racional, dotado de autonomía (Palacios 2011) y que con sus demandas obstaculizaba el "progreso" (Salgado 2012, 97).

14 A partir de 1951 comenzó una campaña institucional de división del campesinado armado. A los campesinos armados de filiación liberal los llamaron limpios y a aquellos que estuvieron ligados directa o indirectamente con el Partido Comunista se los llamó comunes (Salgado 2012, 127). 
bombardeo. Se inició así la Columna de Marcha con mujeres y niños campesinos que caminaban en busca “de refugio en tierras 'más seguras”' (González 1988, 94), dirigiéndose hacia el cañón del río Duda y hacia el llano.

Las mujeres y los niños iban en el centro, organizados en varios contingentes. A los lados, adelante y atrás el anillo guerrillero los defendía y los guiaba. El desplazamiento era muy lento y el hostigamiento muy fuerte. Con todo, tres o cuatro meses después de haber salido de Villarrica y de Cabrera [Sumapaz], la Columna de Marcha llegó al cañón del río Duda. Allí echó raíces como colonia: se fundó. Al fusil se le agregó el hacha. Abrieron la selva, sembraron y cosecharon colectivamente. (Molano 1987, 42)

Aquí vale la pena señalar que se trataba de familias campesinas desplazadas por la violencia política que marchaban, según William Ramírez Tobón (1981), en busca del "renacimiento en otros lugares, de los atributos esenciales a su entidad campesina” (202), es decir, en busca de un lugar donde "fundarse" como campesinos. Posteriormente, del Duda salieron "contingentes de colonos armados y organizados” (Molano 1987, 42) hacia El Pato, Uribe, El Caguán, el Ariari y el Guayabero.

Este proceso de traspaso de la frontera agropecuaria por "grupos de campesinos en armas que acompañados de sus mujeres niños y ancianos, ocupan áreas incultas levantan campamentos y hacen del hacha descuajadora y del fusil el voluntarioso símbolo de la campaña colonizadora” (Ramírez Tobón 1981, 202) es denominado por Ramírez Tobón (1981) colonización armada. Esta última estuvo más presente en Meta, Guaviare y Caquetá que en el Putumayo. Para el caso del Caquetá, Jaramillo (1989) cuestiona a José Jairo González (1992) en cuanto a la extensión geográfica e histórica de este tipo de colonización, pues para él se trató de una limitada fase histórica y en lugares específicos que González amplía en el tiempo y en el espacio. Dicha ampliación lo habría llevado a afirmar, por ejemplo, que las “columnas de marcha” dieron paso a las “zonas de autodefensa”, ya que "un amplio y bien configurado movimiento agrario [...] ejercía la dirección política y militar, administraba justicia, parcelaba y mantenía el control interno de los asentamientos” (González 1992, 63). Para Jaramillo, el que su área de estudio —el Medio y Bajo Caguán- se caracterice por el flujo colonizador "espontáneo” contradice de facto esta prelación que González quiere darle a dicho proyecto político-militar. Tanto Ramírez como González enfatizan la organización armada antes que la organización de las familias campesinas en comunidades o colonias agrícolas que distribuían parcelas de tierra individuales y que les permitían trabajar y vivir en paz. Por su parte, el parlamentario conservador Álvaro Gómez, en un debate en el Senado en 1964, se refirió a estos asentamientos 
campesinos como "repúblicas independientes"15, donde los "bandoleros de los cincuenta”, o guerrilleros liberales, ejercían autoridad como si fueran territorios autónomos. Esta situación, según Gómez, constituía un caldo de cultivo para que pelechara el comunismo y por lo tanto se convertía en una amenaza para la seguridad nacional.

Al respecto, es pertinente tener en cuenta la crítica que hace Fajardo (1998), quien dice que en ambos casos "se ha tratado de caracterizaciones construidas con cargas ideológicas y, de todas maneras, afectadas por un conocimiento insuficiente de los procesos” (14). Por una parte, el imaginario de las repúblicas independientes buscaba legitimar el ataque militar del Estado a estas comunidades campesinas tildadas de comunistas y “donde no se habían logrado imponer los mecanismos de gestión política del bipartidismo” (14); por otra, en el caso de la colonización armada, se trataba principalmente de que tenían "una organización propia que les permitió afrontar muchos de los apremios planteados al asentamiento en territorios desconocidos y aislados del resto de la nación” (14). Fajardo propone calificar este tipo de asentamientos como colonizaciones organizadas, lo cual yo replantearía como colonizaciones campesinas organizadas. En este mismo sentido, Serje (2005) señala que "la asociación colono-guerrilla, corolario del concepto de la colonización armada, se ha extrapolado como caracterización de la colonización” (151), lo cual se cumpliría para el caso de la Amazonia occidental.

Frente a lo anterior, arguyo que, sin proponérselo, esta narrativa de los académicos que se generó en medio de la exaltación de la lucha guerrillera ha sido utilizada por otros para reforzar la representación de los campesinos como bandidos o bandoleros y, posteriormente, como auxiliares de la guerrilla subsumidos en las Fuerzas Armadas Revolucionarias de Colombia (FARC). Esto contribuye a la continua estigmatización del colono de la Amazonia occidental y a su invisibilización como campesino con agencia. En lugar de incluirlos al orden nacional, el Estado prefirió estigmatizarlos, perseguirlos y definirlos como objeto de la violencia estatal, tal como sucedió con el bombardeo a la colonia agrícola de Marquetalia, evento fundacional de la guerrilla campesina de las FARC.

En contraposición a esta tendencia, vale la pena hacer una breve mención a la colonización militar de 1978 en el Putumayo, promovida por el Ministerio de Defensa Nacional. Para este proceso, el Ejército Nacional puso en funcionamiento, en la Inspección de Policía de La Tagua, la Escuela Técnica de Colonización Militar Juan Bautista Solarte Obando. Su objetivo era “desarrollar procesos de

15 Se trata de las regiones de Marquetalia, Riochiquito, alto Sumapaz-Duda, Ariari, Guayabero y El Pato (González 1992). 
colonización planificados que permitieran la 'vitalización de las fronteras' con pleno control sobre la población en proceso de asentamiento” (Culma Vargas 2013, 34-35). A los soldados voluntarios que fueron escogidos por el Ejército, la Armada y la Fuerza Aérea se les instruía en técnicas agropecuarias. Los primeros de ellos se asentaron en 1979 en los predios asignados por el Instituto de Recursos Naturales Renovables (Inderena), en el marco del Proyecto Colonización Militar Dirigida de Puerto Leguizamo a la Tagua diseñado por el Incora (Culma Vargas 2013, 35).

Según Roberto Ramírez (1998), uno de los objetivos de este proyecto fue "frenar la influencia política desde el río Caguán, considerada zona roja por la creciente presencia guerrillera” (80). En este orden de ideas, en 1982 y como resultado del proceso de paz liderado por el presidente Belisario Betancur, se reincorporaron exguerrilleros del M-19 a la vida civil como colonos en los territorios dirigidos por dicha escuela de colonización militar (Culma Vargas 2013, 35). Según Culma, precisamente la consolidación de la economía de coca fue lo que llevó a que este proyecto de colonización dirigida fracasara. De tal manera, en 1988 la escuela de colonización militar se convirtió en el Batallón de Selva n. ${ }^{\circ}$ 49, en donde se adelantaron misiones contra el narcotráfico y contra la guerrilla, lo que confirma la presencia militarista del Estado en esta región de frontera (Ramírez 2019).

\section{De colono campesino a campesino colono}

En su análisis de las diásporas, Clifford (1994) ha propuesto el binomio raíces/ rutas (roots/routes). La distinción nos lleva a pensar en el significado del arraigo y la movilidad como las caras de una misma moneda. Para el caso del colono, su movilidad es entendida como condición de su identidad aun cuando, como hemos visto, el colono campesino busca arraigarse en el lugar en que se "funda". Esta ambivalencia entre el arraigo y el desarraigo ha marcado la representación del colono por parte del Estado, como lo evidencia Brucher ([1968] 1974) al citar la diferencia que establece Wilhelmy entre el campesino y el colono: el primero se vincula a la tierra para producir de manera permanente a través de la mezcla de cultivos, mientras que el colono se representa como un depredador que "no se siente con ninguna obligación respecto al suelo que cultiva: lo explota hasta dejarlo agotado y luego busca tierra nueva dentro de la selva” (143).

En el caso de La Macarena, en Meta, los primeros colonos provenían de Caquetá, lo cual los convertía en “colonos de segunda generación” (Leal 1995, 47). 
Esto se cumplió también en el caso de quienes llegaron a la Baja Bota Caucana (Ramírez 2001), caracterizados por mantener vínculos con los lugares de donde provenían. El trasegar de un lugar al otro los seguía identificando como colonos.

En consonancia con una imagen del colono según la cual "se encuentra en la frontera agrícola y [...] ha vivido en un continuo éxodo” (Torres 2010, 107), surge otra categoría a la que se refiere Alfredo Molano (1988) y que retomaron los funcionarios del Incora en Caquetá: colonos profesionales, especializados en tumbar selva virgen para vender las mejoras a los especuladores de tierra y continuar abriendo frentes de colonización selva adentro (Martínez 2017, 127; Molano 1988, 104). En el caso de La Macarena, Claudia Leal (1995) propone hablar de la ampliación de la

“frontera ganadera” [ya no agropecuaria, como propone Culma, ni agrícola por considerarla "un mito"] que obliga a que los colonos vuelvan a moverse y repitan el ciclo de tumba, cultivo y siembra de pastos para vender nuevamente las “mejoras” a quien pague más por ellas. (18)

Sin embargo, Acero (s. f.) afirma que muy pocos colonos acceden "a una propiedad estable y próspera económicamente [de manera que] a otros solo les queda la salida de vender sus mejoras para iniciar el ciclo económico como colonos en otro frente” (218). Entonces, en estas zonas ganaderas de Guaviare (Acero s. f.) —Caquetá (Ciro 2008) y Meta (Gómez 1991)—, este tipo de colonos se hizo más visible, con lo cual se reitera su condición de movilidad y desarraigo.

Sin embargo, es necesario explorar la otra cara de la moneda de la consolidación de los colonos como campesinos colonos. Así, una vez asentados en sus predios, tras llevar a sus familias - porque en principio migraba solo el jefe de familia-y establecer una economía campesina “andina”, se empezó a construir una relación de pertenencia a la región para lo cual resultó central la posesión de un pedazo de tierra. En ese momento empezó a primar su condición de campesino sobre la de colono, sin que esta última categoría se descartara del todo como una memoria indeleble de su lugar de procedencia.

En referencia al colono temprano, Acero (s. f.) señala que este aprendió a reconocer las diferentes calidades de tierra y pudo seleccionar tierras de vega que le permitían tener una mejor producción agrícola. Estamos frente a los colonos fundadores a los que se refiere Vásquez (2006) para el caso de Vistahermosa en el Meta y que se definen a sí mismos, haciendo referencia a su búsqueda de titulación, como "los que luchan por hacer el fundo, los primeros que llegan y los que sacan permiso” (testimonio en Vásquez 2006, 190). El tiempo de permanencia en la región va a establecer jerarquías, de manera que la antigüedad no solo se traduce en posesión "legal” de tierras, sino “en una posición más elevada en la 
sociedad [...] [Los más antiguos] reclaman las cualidades morales más elevadas para gobernar y decidir sobre el destino del municipio” (Vásquez 2006, 190).

Por su parte, en su estudio del Medio y el Bajo Caguán, Jaramillo (1989, 44-45) muestra el proceso de construcción, paulatino y no deliberado por parte de los colonos, de "un tipo de agrupación comunitaria de base territorial” que se constituye en la vereda, que genera "un particular sentimiento de pertenencia e identidad común” y que se traduce en "relaciones primarias” que promueven formas de ayuda mutua, más allá del parentesco y de la propiedad colectiva del suelo. Como lo señala Del Cairo (1998), para “progresar”, los colonos necesitan de la ayuda de sus vecinos, "lazos que se afianzan a medida que los fundos se transforman en fincas” (79). Entre estas prácticas sobresalen las de la manodevuelta o manoprestada para el establecimiento del colono (Acero s. f., 217). Las relaciones de vecindad en la vereda llevan a la cohesión social y a la emergencia de formas de socialización distintas a la familia, pero sobre todo a la emergencia de las juntas de acción comunal y de los comités de colonos como organizaciones que los representan (Acero s. f.; Jaramillo 1989).

Para el caso del Guaviare, en 1981 se creó el Comité Cívico-Campesino en Calamar, organización que les permitió a los campesinos colonos no solo realizar trabajos colectivos, como el mejoramiento de trochas y la construcción de puentes, sino demandarle bienes públicos al Estado. Así, en 1983 se creó un sindicato de pequeños agricultores que reprodujo la organización política de sus lugares de origen (Salgado 2018). Un testimonio presentado por Acero (s. f.) menciona el debate de unos colonos de La Macarena ante el dilema de si crear una Junta de Acción Comunal o un sindicato; según se cuenta, los colonos terminaron decantándose por la primera porque, como dicen, “allí cabemos todos, propietarios y jornaleros... somos personas que necesitamos estar dentro de la ley” (citado en Acero s. f., 221). Toda forma de legalización de su asentamiento es acogida. Fajardo (1996) llega al punto de afirmar que:

el vacío del Estado comienza a ser llenado por el desarrollo de los gérmenes de organización que traen los colonos y con los cuales buscan soluciones a sus necesidades de educación, salud, vías, etc. Es la magnitud del germen de un nuevo Estado. (262)

En este orden de ideas, Fajardo $(1996,267)$ sugiere que estos fenómenos nos ponen frente a la formación de una "cultura mestiza” en el medio amazónico que asimila, interpreta y desarrolla tradiciones a lo largo del tiempo en la región. Esto también reivindica el intercambio de conocimiento entre colonos e indígenas (Pijnemburg 1988). Se trata de una línea similar a la de Useche (1989), quien ha querido complejizar la composición étnica de los colonos y sus reivindicaciones 
culturales al sugerir que no se puede equiparar colono con blanco, y al resaltar su condición de mestizos. Es posible afirmar que el ser mestizo cobra importantica identitaria para el campesino colono cuando se consolida la colonización del piedemonte amazónico.

A pesar de estas consideraciones, la imagen del colono depredador del medio ambiente retoma inusitada importancia en el contexto actual, en el que el discurso de conservación ambiental se ha vuelto hegemónico y contrapone a los indígenas, como conservacionistas innatos, y a los colonos que, solo por el hecho de serlo, son considerados depredadores. Para Rincón (2018), a partir de 1981, en el discurso de la prensa nacional se inauguró el periodo del "estigma y la conservación” con respecto a la representación del campesino-colono de la Amazonia, en el que su imagen "como valiente y arrojado se torna mayoritariamente negativa [por considerarlo] destructor de la vegetación original” (131). De esta manera, no se reconoce ni comprende "el sistema de conocimiento de los campesinos colonos” forjado durante años de permanencia en la región (Del Cairo 2019, 128). En este sentido, Del Cairo (2019) sostiene que "los colonos transitaron a una condición de sujetos incultos que les niega de tajo la posibilidad de tener conocimientos prácticos y sostenibles para relacionarse con la selva” (129). Se trata de un tránsito que deja de lado la discusión o caracterización de la "cultura mestiza”, propia de los campesinos colonos de la región amazónica antes mencionada. Más aún, se ha redefinido la condición para la titulación de tierras que durante la segunda mitad del siglo XX había requerido a los colonos en zonas de frontera talar o "desmontar" tres cuartos de sus parcelas para adaptarlas a cultivos o pastos para el ganado. En palabras de Del Cairo (2019), "la esperanza de la titulación de sus fundos pasaba por imprimirle mucha fuerza de trabajo a la selva, transformarla y en últimas civilizarla” (112).

\section{Entre campesino colono, colono cocalero y campesino cocalero}

En la década de los setenta, en un estudio de investigadores del Instituto Geográfico Agustín Codazzi (IGAC) sobre "la imagen del colono” en Putumayo, se afirma que "el drama que el campesino vivía en el lugar de origen se reproduce - con algunas variantes - en la zona de colonización” (Camacho y Vallejo 1972, 115), esto por cuanto no lograba acceder fácilmente a la propiedad de la tierra por la falta de vías y de servicios técnicos y financieros, así como por la explotación 
de prestamistas, transportadores y comerciantes. Aunque se registra la existencia de "colonos ricos", se definen como aquellos "que han tenido un mínimo de ventajas sobre los colonos más pobres [y que] han logrado imponer a lo largo del tiempo esta ventaja mínima” (Camacho y Vallejo 1972, 113).

Estos campesinos colonos vieron llegar el cultivo de coca a la región de la Amazonia occidental a finales de los años setenta. Rápidamente, dichos cultivos se expandieron para dar origen al primer boom en 1981 que, sostenido hasta 1987, dio lugar a una nueva ola de colonización y a la diferenciación de clase social encarnada particularmente en "los nuevos colonos que han migrado tras el espejismo de la coca” (Jaramillo 1986, 59), es decir, los colonos cocaleros que llegaron con el objetivo específico de cultivar coca. A ellos, en una noticia de El Tiempo del 30 de enero de 1980 se los denomina "los colonos de la mafia" (Rincón 2018, 137).

La condición de ilegalidad del cultivo de la hoja de coca la convierte en la "la mata que mata”, tal como aparecía en 2009 en una propaganda gubernamental que reducía sus propiedades como cultivo agrícola a su simple transformación en cocaína. Adicionalmente, esta condición hace que el cultivador pierda su reconocimiento como campesino colono al quedar subsumido por el rótulo de colono cocalero. Para la década del ochenta, el colono-campesino era representado en la prensa nacional como "enemigo del Estado y calificado como narcocultivador, coquero, cocacultivador y narco del siglo XX entre otros” (Rincón 2018, 131). Como consecuencia, los campesinos colonos vieron roto su proceso de integración al orden nacional, dado que se inició su criminalización en el marco de la Ley 30 de 1986 o Estatuto Nacional de Estupefacientes — que determina años de prisión y multas según la cantidad de plantas de coca sembradas-y de la fumigación aérea de sus cultivos de coca.

Con esta expansión y consolidación del cultivo de coca, la categoría de colono criminal se traslapa con la representación de campesino ilícito a la que se refiere William Ramírez Tobón (1996), predominante en el caso de los campesinos cultivadores de coca. Dicha categorización da lugar a "la imagen de un campesino criminal que cambia su vocación de siembra natural para el chontaduro, el caucho y el maíz por el proditorio cultivo de la coca, la amapola y la marihuana” (Ramírez Tobón 1996, 55).

Sin embargo, a la vez que se criminalizó al cultivador de coca, en 1985 el Programa de las Naciones Unidas para la Fiscalización Internacional de las Drogas (UNDCP) incluyó el desarrollo alternativo con el fin de sustituir los cultivos de coca por cultivos "legales". Con ello también se introdujo "el reconocimiento de los cultivadores de pequeña escala de plantas de uso ilícito” (Iglesias 2003, 19). En 1986 ya se habían iniciado proyectos de sustitución en Caquetá, Guaviare y 
Putumayo (Ramírez e Iglesias 2010). Este reconocimiento conllevaba también el de las condiciones de pobreza y marginalidad de las regiones en donde florecían los cultivos de uso ilícito, la falta de infraestructura, la presencia de actores armados y narcotraficantes — quienes, se dice, financiaban a los campesinos para cultivar la mata de coca- En estas condiciones, los campesinos cultivadores se convertían en "pequeños cultivadores de materias primas ilícitas” (UNDCP 1998, 68). Así mismo, en 1985, durante el gobierno de Belisario Betancur y después de la firma de los Acuerdos de la Uribe (Meta) el 28 de marzo de 1984, los mismos colonos, a través de sus organizaciones comunitarias, tomaron la decisión de transformar su base económica sustentada en el cultivo de la coca (Mora 1989). Para ello, presentaron la primera propuesta de sustitución de cultivos de coca incluida en el Plan de Desarrollo del Bajo y Medio Caguán, que no se logró implementar.

El desarrollo alternativo se convirtió en política nacional diez años después de esta propuesta (Conpes 2734 de 1994) (DNP 1994) y posteriormente se transformó en un programa presidencial denominado Plan Nacional de Desarrollo Alternativo (Plante) (Conpes 2799 de 1995) (DNP 1995). En el Conpes de 1994 se diferencian los cultivos ilícitos para la subsistencia y los cultivos ilícitos comerciales. Así, cuando el Plante establece la población objetivo del desarrollo alternativo, omite a quienes se identifican como colonos, considerando "que hacen parte de la colonización coquera y la colonización amapolera” (Presidencia de la República de Colombia 1996, 3) y se aclara que "no siempre son campesinos, pues muchos provienen de las ciudades, no tienen la menor intención de quedarse en las tierras que ocupan y son financiados por los comerciantes de estupefacientes” (3); además, menciona que:

no les importa el daño que están causando al derribar los bosques y contaminar las aguas con los desechos químicos de los cultivos ilícitos y del procesamiento de sustancias narcóticas [de manera que] si las fuerzas del orden les erradican las plantaciones se desplazan a otros sitios a tumbar montaña, siempre y cuando los narcotraficantes los sigan financiando. (Presidencia de la República de Colombia 1996, 3)

El desarraigo y la depredación reaparecen como parte de la imagen del colono. Se reitera, además, que el programa se dirigirá “a los campesinos afectados por los cultivos ilícitos”, es decir, a pequeños productores campesinos e indígenas asentados en estas zonas, "sea que siembren o no cultivos ilícitos como parte de su sistema de producción y como medio de subsistencia” (DNP 1994, 15). Iglesias (2003) destaca que, al omitirse el concepto de colono en esta política pública, el Estado "hace que se privilegie implícitamente la representación de un campesino no criminal que no es culpable de su situación y explícitamente se comienza a plantear al colono como el perverso [o el criminal]” (39). Este señalamiento 
confirma la aparición de una nueva categoría: la de colono cocalero, en oposición a la de colono campesino (de los años sesenta y setenta).

Esta categoría corresponde a sujetos sometidos a las políticas represivas que llevan a su criminalización, que son despojados de sus derechos y que, por consiguiente, no son considerados interlocutores válidos para negociar con el Estado. Al mismo tiempo, esta diferenciación implica el reconocimiento de zonas de colonización antigua y de zonas de colonización reciente. En las primeras se encontraban los colonos campesinos, convertidos en campesinos colonos, que llegaron antes de la década de los setenta y cuya principal motivación para migrar, se reconoce, fue "la satisfacción de su demanda por tierra con miras a consolidarse como pequeños productores rurales” (DNP 1996); para ellos, la coca sería solo uno de los cultivos de subsistencia (Ramírez 2001). Jaramillo (1989, 122), por su parte, insiste en que se deben diferenciar los intereses y motivaciones del colono tradicional que llegó en los años sesenta y setenta de aquellos que tenían los que llegaron posteriormente atraídos por la "bonanza” de la coca.

Con todo, en el Conpes 2799 de 1995 se representa al colono de la mano del cultivador comercial de coca y, por consiguiente, como sujeto a las políticas de criminalización antes que a las de desarrollo alternativo. De esta forma, se revivía una actitud ambivalente frente al colono como migrante. De manera similar, se representó así a la Amazonia occidental como una región habitada por colonos desarraigados en busca de dinero fácil y dedicados a actividades ilegales, ya fuera por relacionarse con narcotraficantes o con grupos armados no estatales. Así, los colonos resultaban rotulados, además, como auxiliares de la guerrilla, lo cual evidencia el vínculo entre guerra contrainsurgente y guerra contra las drogas que ha caracterizado la política antidrogas en Colombia, como lo han señalado diversos autores (Gutiérrez Sanín 2020; Ramírez 2001; Vargas 1999).

En el marco de las conversaciones de paz del gobierno de Andrés Pastrana con las FARC en el Caguán (1999-2002) se realizó una audiencia pública llamada "Medioambiente y cultivos de uso ilícito", a la que asistieron organizaciones campesinas y veinticinco embajadores de la Unión Europea. En ella, las FARC propusieron a Cartagena del Chaira (Caquetá) como lugar piloto para plantear de nuevo un programa de sustitución de cultivos de coca. Esta propuesta no fue aceptada por el Gobierno en ese momento, pero dio lugar a la idea de conformar la Coordinadora de Cultivadores de Coca del país. Como lo contó la finada líder Luz Perly Córdoba (Osorio Granados 2017), se trató de una iniciativa que, aunque no tuvo mayor vigencia, buscaba reivindicar su condición de pequeños campesinos cultivadores de coca. Se trata del campesino cocalero al que Estefanía Ciro $(2020,270)$ define para el Caquetá como aquel con menos de 3 ha de cultivos que, además de la coca, tiene otras actividades agrícolas y pecuarias, quiere 
permanecer en el campo y privilegia la ganadería como el principal renglón para reconvertir su economía.

En octubre de 2012 se instalaron los diálogos de paz con las FARC en La Habana y en 2013 se organizaron asambleas nacionales y regionales - en manos de las Naciones Unidas y la Universidad Nacional de Colombia- para consultar y nutrir las discusiones sobre el punto cuarto de la agenda, relativo al problema de los cultivos ilícitos. En este contexto, se revivió la idea de la Coordinadora Nacional de Cultivadores de Coca con el objetivo de poner fin a la satanización de la hoja de coca y devolverle su condición de planta agrícola. Así, a finales de enero de 2017, al mismo tiempo que el Gobierno y las FARC iniciaban el Programa Nacional Integral de Sustitución de Cultivos de Uso Ilícito (PNIS), en Popayán se lanzó la Coordinadora de Cultivadores de Coca, Amapola y Marihuana (Coccam), con la participación de campesinos, indígenas y afrodescendientes provenientes de catorce departamentos. Así lo explicaba Luz Perly Córdoba:

Los campesinos siempre han estado organizados [...] donde hay coca, en comités cocaleros, esto no es un secreto para nadie. Lo que hemos hecho ahora es recoger todos estos procesos locales y regionales y conformar la coordinación nacional con el fin de convertirnos en un actor determinante en el tema de la solución al problema de los cultivos de uso ilícito [...] la idea es que en la medida en que vayan acabando los cultivos ilegales y los campesinos vayan haciendo tránsito hacia una economía lícita, sigan siendo parte de sus asociaciones campesinas como siempre lo han hecho, ya no como cocaleros sino como productores agrícolas lícitos [...] La idea es avanzar con una verdadera solución al problema, lo cual tiene que ver con el desarrollo rural integral. (Osorio Granados 2017)

Así, se concretaba la organización que se había tratado de formar después de las marchas cocaleras de 1996 (Ramírez 2001) y que en ese momento no se hizo realidad. Se requirieron veinte años de lucha para que se reconociera a los cultivadores de coca como campesinos. Finalmente, cabe resaltar que, recientemente, este reconocimiento se ha ampliado a la reivindicación de sus derechos culturales (Ramírez 2017), como se evidencia en el hecho de que el pequeño cultivador de coca se ha sumado a la actual lucha del campesinado por su reconocimiento como sujeto político con derechos diferenciados (Güiza et al. 2020; Gutiérrez 2019). Lo anterior implica reivindicar su condición de grupo sociocultural con identidades y prácticas propias, en el marco de la Constitución de 1991 (Ramírez 2017).

En conclusión, a lo largo del análisis de la genealogía de la categoría colono en diferentes contextos históricos, se evidenció cómo es celebrado por su arrojo y valentía cuando se inician los procesos de colonización de las periferias y cómo 
se le estigmatiza como bandolero por estar armado y asociársele con la guerrilla en otras coyunturas. Así mismo, el colono fue sujeto de programas del Estado que sustituyeron la reforma agraria en el interior del país, pero al no lograr éxito en su sostenibilidad, tuvo que cultivar la hoja de coca, lo cual lo llevó a ser estigmatizado como narcoculitvador, aunado a ser considerado depredador del medio ambiente. Es necesario resaltar que el denominado colono es una figura fundamental para entender la categoría de campesino, puesto que en ciertos momentos el ser campesino hace parte de la condición del colono; en otros, una categoría puede subsumir a la otra y, en otros más, las dos pueden encontrarse en tensión, si es que no en oposición. A pesar de todas estas manifestaciones situadas, es un hecho que el ser campesino es un estado al que espera llegar el colono en busca de su desestigmatización por parte del Estado y del reconocimiento tanto de la propiedad de su predio como de sus derechos como campesino.

\section{Referencias}

Acero, Hugo. s. f. "El colono”. En Colonización del bosque húmedo tropical, editado por Corporación Araracuara y Fondo de Promoción de la Cultura, 215-226. Bogotá: Gente Nueva.

Alonso, Irene. 2020. "La voz campesina en la esfera pública colombiana en el siglo XX a través de los periódicos de la ANUC y sus antecedentes”. Tesis de pregrado en Antropología, Departamento de Antropología, Pontificia Universidad Javeriana, Bogotá.

Appelbaum, Nancy. 2003. Muddied waters. Race, religion and local history in Colombia 18461948. Durham: Duke University Press.

Arias Vanegas, Julio. 2007. Nación y diferencia en el siglo XIX colombiano. Orden nacional, racialismo y taxonomías poblacionales. Bogotá: Ediciones Uniandes.

Arias Vanegas, Julio e Ingrid Johanna Bolívar. 2006. "El cultivo de la identidad natural. Paisaje, cultura y turismo en Montenegro, Quindío". En Identidades culturales y formación del Estado en Colombia: colonización, naturaleza y cultura, editado por Ingrid Johanna Bolívar, 51-118. Bogotá: Ediciones Uniandes.

Aristizábal, Silvio. 2016. "El imaginario sobre la raza antioqueña”. Consultado el 14 de julio de 2021. https://pensilvaniaciento50.wordpress.com/2016/08/01/el-imaginario-sobre-laraza-antioquena/

Barrera, Rafael. 1963. Aspectos de la reforma agraria en Colombia. Antecedentes, progreso y comentarios. Ciudad de México: Instituto de Investigaciones Sociales / Universidad Nacional de Colombia.

Bhabba, Homi K. (1994) 2007. El lugar de la cultura. Traducido por César Aira. Buenos Aires: Ediciones Manantial. 
Brucher, Wolfgang. (1968) 1974. La colonización de la selva pluvial en el piedemonte amazónico en Colombia. El territorio comprendido entre el río Ariari y el Ecuador (1968). Bogotá: Instituto Geográfico Agustín Codazzi.

Camacho, Álvaro y Jorge Vallejo. 1972. "Imagen del colono. Estudio de casos y visión general de su situación”. Revista del Instituto Geográfico Agustín Codazzi III (1): 101-139.

Casas Aguilar, Justo. 2001. "Entre el hacha y la cruz. La colonización del Putumayo: 18941930”. En Historia general del departamento de Putumayo. Texto guía para la enseñanza, editado por Augusto Gómez López , 407-515. Bogotá: Universidad Nacional de Colombia. Manuscrito inédito.

Charry Sedano, Alicia. 1991. "Contacto, colonización y conflicto en el Valle de Sibundoy: 1870-1930”. Tesis de pregrado en Antropología, Departamento de Antropología, Universidad de los Andes, Bogotá.

Chaves, Margarita. 1998. "Identidad y representación entre indígenas y colonos de la Amazonia colombiana”. En Modernidad, identidad y desarrollo, editado por María Lucía Sotomayor, 283-296. Bogotá: ICANH; Ministerio de Cultura.

Chaves, Milcíades. 1945. "La colonización de la Comisaría del Putumayo. Un problema etnoeconómico-geográfico de importancia nacional”. Boletín de Arqueología 1 (6): 567-598. https://www.icanh.gov.co/recursos_user//ICANH\%20PORTAL/SUBDIRECCI\%C3\%93N\%20 CIENT\%C3\%8DFICA/ANTROPOLOGIA/Bolet\%C3\%ADn\%20de\%20arqueolog\%C3\%ADa/ Vol(1).\%201,\%20n.\%206f.pdf

Ciro, Claudia Alejandra. 2008. De la selva a la pradera: reconfiguración espacial del piedemonte caqueteño. Documento n. ${ }^{\circ}$ 159, Departamento de Historia. Bogotá: Centro de Estudios Socioculturales, Facultad de Ciencias Sociales / Universidad de los Andes.

Ciro, Estefanía. 2020. Levantados de la selva. Vidas y legitimidades en los territorios cocaleros del Caquetá. Bogotá: Ediciones Uniandes.

Clifford, James. 1994. "Diasporas”. Cultural Anthropology 9 (3): 302-338. http://www.jstor. org/stable/656365

Congreso de Colombia. 1890. Ley 89, 25 de noviembre. "Por la cual se determina la manera como deben ser gobernados los salvajes que vayan reduciéndose a la vida civilizada". Diario Oficial XXVI (8263), 8 de diciembre, 1. http://www.suin-juriscol.gov.co/viewDocument. asp?ruta=Leyes/1630995

—. 1914. Ley 69, 12 de noviembre. "Por la cual se reforman las Leyes 51 de 1911 y 106 de 1913". Diario Oficial MCMXIV (15344), 12 de noviembre, 1. http://www.suin-juriscol.gov.co/viewDocument.asp?id=1619381

-. 1959. Ley 29, 4 de agosto. "Por la cual se fomenta la repatriación de los capitales colombianos poseídos en el Exterior, se autoriza la emisión de bonos nacionales en moneda extranjera y se crea un Fondo de Desarrollo Económico”. Diario Oficial XCVI (30021), 13 de agosto, 313. http://www.suin-juriscol.gov.co/viewDocument.asp?ruta=Leyes/1585565

-. 1961. Ley 135, 15 de diciembre. "Sobre la reforma social agraria". Diario Oficial XCVIII (30691), 20 de diciembre, 801. http://www.suin.gov.co/viewDocument.asp?id=1792699

-. 1986. Ley 30, 31 de enero. Estatuto Nacional de Estupefacientes. Diario Oficial CXXII (37335), 5 de febrero, 5. http://www.suin-juriscol.gov.co/viewDocument.asp?ruta=Leyes/ 
1586799\#: :text=El\%20Consejo\%20Nacional\%20de\%20Estupefacientes,de\%20drogas\%20 que\%20produzcan\%20dependencia.

Culma Vargas, Edinso. 2013. "Militares, parentesco y la construcción el estado local en Leguízamo (Putumayo)”. Tesis de Maestría en Antropología, Programa de Antropología, Facultad Latinoamericana de Ciencias Sociales (Flacso), sede Ecuador, Quito.

Dainco (Departamento Administrativo de Intendencias y Comisarías). 1982. "Cuatro años de esfuerzo dedicado al desarrollo integral de las intendencias y comisarías 19781982”. Archivo Nacional, Archivo Dainco. Bogotá. Documento inédito.

Del Cairo Silva, Carlos Luis. 1998. "Tucanos y colonos del Guaviare. Estrategias para significar el territorio”. Revista Colombiana de Antropología 34: 66-91. https://revistas.icanh.gov. co/index.php/rca/article/view/1330

-. 2019. "Selvas y gentes (in)cultas: políticas de la cultura y poblaciones amazónicas en los diseños de intervención estatal”. En Cultura: centralidad, artilugios, etnografía, editado por la Asociación Colombiana de Antropología, 107-147. Popayán: Samava Ediciones EU.

DNP (Departamento Nacional de Planeación). 1994. Programa de Desarrollo Alternativo. Documento Conpes 2734. Bogotá. http://www.mamacoca.org/docs_de_base/Cifras_cuadro_mamacoca/DR-DesarrolloAlternativo\%20Conpes_1994.pdf

—. 1995. Plan Nacional de Desarrollo Alternativo II. Plante. Documento Conpes 2799. Bogotá. https://colaboracion.dnp.gov.co/CDT/Conpes/Econ\%C3\%B3micos/2799.pdf

-. 1996. Documento Conpes 2835. https://colaboracion.dnp.gov.co/CDT/CONPES/Econ\%C3 \%B3micos/2835.pdf

Fajardo, Darío. 1996. "Fronteras, colonizaciones y construcción social del espacio”. En Frontera y poblamiento: estudios de historia y antropología de Colombia y Ecuador, editado por Chantal Caillavet y Ximena Pachón, 237-282. Bogotá: IFEA; Sinchi; Universidad de los Andes.

-.1998. Prólogo a Atlas cultural de la Amazonia colombiana. La construcción del territorio en el siglo XX, por Eduardo Ariza, María Clemencia Ramírez y Leonardo Vega, 13-15. Bogotá: ICANH; Ministerio de Cultura; Corpes Orinoquia; Corpes Amazonia.

-. 2018. “Agricultura, campesinos y alimentos (1980-2010)”. Tesis doctoral en Estudios Sociales, Facultad de Ciencias Sociales y Humanas, Universidad Externado de Colombia, Bogotá.

Ferro, Juan Guillermo y Graciela Uribe. 2004. "Las marchas de los cocaleros del departamento de Caquetá, Colombia: contradicciones políticas y obstáculos a la emancipación social”. En Emancipación social y violencia en Colombia, editado por Boaventura de Sousa Santos y Mauricio García Villegas, 119-152. Bogotá: Editorial Norma.

Gómez, Augusto. 1991. Indios, colonos y conflicto. Una historia regional de los Llanos Orientales. 1870-1970. Bogotá: Siglo XXI Editores; Pontificia Universidad Javeriana; ICANH.

-. 2010. Putumayo. Indios, misión, colonos y conflictos (1845-1970). Colección Bicentenario, serie Historiografía. Popayán: Universidad del Cauca.

González, José Jairo. 1988. "El Ariari y el Caguán. Dos vertientes colonizadoras de la Amazonia colombiana”. Colombia Amazónica 3 (2): 89-98.

—.1992. El estigma de las repúblicas independientes 1955-1965. Bogotá: Cinep. 
González, José Jairo y Elsy Marulanda. 1990. Historias de frontera. Colonización y guerras en el Sumapaz. Bogotá: Cinep.

Guhl, Ernesto. 1982. "El papel de la geografía en las ciencias humanas”. Revista Colombiana de Sociología 2: 82-128. https://revistas.unal.edu.co/index.php/recs/article/view/8636

Güiza, Diana Isablel, Ana Jimena Bautista, Ana María Malagón y Rodrigo Uprimny. 2020. La constitución del campesinado. Luchas por reconocimiento y redistribución en el campo jurídico. Bogotá: Dejusticia.

Gutiérrez Sanín, Francisco. 2019. “Tensiones y dilemas de la producción cocalera”. Análisis Político 97: 71-90. https://doi.org/10.15446/anpol.v32n97.87193

-. 2020. "Fumigaciones, incumplimiento, coaliciones y resistencias". Estudios Socio-jurídicos 22 (2): 1-37. https://doi.org/10.12804/revistas.urosario.edu.co/sociojuridicos/a.9146

Iglesias, Juliana. 2003 "Representaciones en el discurso estatal de los pequeños cultivadores de plantas de usos ilícitos (1994-2002)”. Tesis de pregrado en Antropología, Departamento de Antropología, Universidad de los Andes, Bogotá.

Jaramillo, Jaime Eduardo. 1989. "Historia y dimensiones socioculturales del proceso colonizador”. En Jaramillo, Mora y Cubides 1989, 1-130.

Jaramillo, Jaime, Leonidas Mora y Fernando Cubides, eds. 1989. Colonización, coca y guerrilla. Bogotá: Alianza Editorial Colombiana.

Karl, Robert. 2017. Forgotten peace: reform, violence and the making of contemporary Colombia. Oakland: University of California Press.

Laclau, Ernesto. 1990. New reflections on the revolution of our time. Londres: Verso.

Leal, Claudia. 1995. A la buena de Dios. Colonización en La Macarena, ríos Duda y Guayabero. Bogotá: Seres; Fescol.

LeGrand, Catherine. (1986) 2017. Colonización y protesta campesina en Colombia (1850-1950). Bogotá: Ediciones Uniandes; Universidad Nacional de Colombia; Cinep.

Londoño, Rocío. 2011. Juan de la Cruz Varela. Sociedad y política en la región de Sumapaz (1902-1984). Bogotá: Universidad Nacional de Colombia.

Martínez, Sandra Patricia. 2017. Encuentros con el Estado. Burocracias y colonos en la frontera amazónica (1960-1980). Cali: Editorial Universidad del Valle.

Melo, Jorge Orlando. 2013. “¿Raza antioqueña?”. El Tiempo, 14 de agosto. https://www.eltiempo.com/archivo/documento/CMS-12992040

Molano, Alfredo. 1987. Selva adentro. Una historia oral de la colonización del Guaviare. Bogotá: El Áncora Editores.

—. 1988. "Algunas consideraciones sobre la colonización y la violencia”. Colombia Amazónica 3 (2): 99-110.

Mora, Leonidas. 1989. “Las condiciones económicas del Medio y Bajo Caguán”. En Jaramillo, Mora y Cubides 1989, 131-227. 
Osorio Granados, Marcela. 2017. "La erradicación forzada va a generar un conflicto social”. El Espectador, 26 de enero. https://www.elespectador.com/colombia-20/conflicto/la-erradicacion-forzada-va-a-generar-un-conflicto-social-article/

Palacios, Marco. 2011. ¿De quién es la tierra? Propiedad, politización y protesta campesina en la década de 1930. Bogotá: Fondo de Cultura Económica; Ediciones Uniandes.

Pijnemburg, Tom. 1988. "Cambios de sistemas de producción y adquisición de conocimientos entre colonos blancos y colonos indígenas en la frontera agrícola colombiana. Colombia Amazónica 3 (2): 83-88.

Presidencia de la República de Colombia. 1928. Decreto 1110, 14 de junio de 1928. "Por el cual se destinan zonas para colonización".

—. 1996. “Qué es el Plante”. El Espectador, fascículo n. ${ }^{\circ}$ 2, serie “Así es el Plante”, 27 de agosto. Plan Nacional de Desarrollo Alternativo de la Presidencia de la República.

Ramírez, María Clemencia. 2001. Entre el Estado y la guerrilla: identidad y ciudadanía en el movimiento de los campesinos cocaleros del Putumayo. Bogotá: ICANH; Colciencias.

-. 2015. "The idea of the State in Colombia: an analysis from the periphery". En State theory and Andean politics. New approaches to the study of rule, editado por Christopher Krupa y David Nugent, 35-55. Filadelfia: University of Pennsylvania Press.

-. 2017."Las conversaciones de paz en Colombia y el reconocimiento de los cultivadores de coca como víctimas y sujetos de derechos diferenciados”. Canadian Journal of Latin American and Caribbean Studies 42 (3): 350-374. https://doi.org/10.1080/08263663.2017.1379135

- 2019. "Militarism on the Colombian periphery in the context of illegality, counterinsurgency and the post-conflict”. Current Anthropology 60 (19): S134-S147. https://www.journals.uchicago.edu/doi/full/10.1086/699970

Ramírez, María Clemencia y Juliana Iglesias. 2010. "Paradojas del desarrollo alternativo en la Amazonia occidental colombiana”. En Perspectivas antropológicas sobre la Amazonia contemporánea, compilado por Margarita Chaves y Carlos Luis del Cairo, 537-562. Bogotá: ICANH; Pontificia Universidad Javeriana.

Ramírez, Roberto. 1998. “Conflictos sociales en el Putumayo”. En Conflictos regionales. Amazonia y Orinoquia, editado por Fescol, 71-129. Bogotá: Fescol; Iepri.

Ramírez Tobón, William. 1981. "La guerrilla rural en Colombia. ¿Una vía hacia la colonización armada?”. Estudios Rurales Latinoamericanos 4 (2): 199-209.

—. 1996. “¿Un campesinado ilícito?”. Análisis Político 29: 54-62. https://revistas.unal.edu.co/ index.php/anpol/article/view/74971

Rincón, Laura. 2018. "De cándidos a malhechores: representación de los campesinos-colonos del Caquetá en la prensa nacional, 1948-1991”. Tesis de Maestría en Estudios Amazónicos, Universidad Nacional de Colombia, sede Amazonía, Leticia.

Salgado, Henry. 2012. "El campesinado de la Amazonia colombiana: construcción territorial, colonización forzada y resistencias”. Tesis doctoral en Antropología, Departamento de Antropología, Facultad de Artes y Ciencias, Montreal University, Canadá. 
-. 2018. Don Armando Montaña Ríos. Una historia de la acción colectiva del Guaviare, 19702010. Bogotá: Pontificia Universidad Javeriana.

Sánchez Gómez, Gonzalo. 1988. “Rehabilitación y violencia bajo el frente nacional”. Análisis Político 4: 21-42. https://revistas.unal.edu.co/index.php/anpol/article/view/74062

Sánchez Gómez, Gonzalo y Donny Meertens. 1983. Bandoleros, gamonales y campesinos. El caso de La Violencia en Colombia. Bogotá: El Áncora Editores.

Serje, Margarita. 2005. El revés de la nación. Territorios salvajes, fronteras y tierras de nadie. Bogotá: Ediciones Uniandes.

Serrano, Edgard David. 1994. El modelo ganadero de la gran hacienda. Florencia: Universidad de la Amazonia.

Torres Bustamante, María Clara. 2010. “PPuede un campesino cocalero contribuir a la regulación política y a la gobernanza?”. En Gobernanza y conflicto en Colombia. Interacción entre gobernantes y gobernados en un contexto violento, editado por Claire Launay-Gama y Fernán González, 103-108. Bogotá: Cinep; Pontificia Universidad Javeriana.

-. 2020. “The roots of an illicit peasant crop: Colombia 1950s-1990s”. Tesis doctoral, Departament of History, Stony Brook University, Nueva York.

Tovar, Hermes. 1995. Que nos tengan en cuenta. Colonos, empresarios y aldeas: Colombia 1800-1900. Bogotá: Tercer Mundo Editores; Colcultura / Premio Nacional de Cultura 1994.

UNDCP (Programa de las Naciones Unidas para la Fiscalización Internacional de Drogas). 1998. Colombia. Apoyo y compromiso integrales. Bogotá: UNDCP.

Useche Losada, Mariano. 1989. "La cuestión étnica y el desarrollo regional en la Amazonia colombiana”. En Amazonia, identidad y desarrollo, editado por Fundación Manoa y Fondo Fen, 53-61. Bogotá: FEN.

Vargas, Ricardo. 1999. Drogas, máscaras y juegos. Narcotráfico y conflicto armado en Colombia. Bogotá: Tercer Mundo Editores; TINI-Acción Andina.

Vásquez, María de la Luz. 2006. "De repúblicas independientes a zona de despeje. Identidades y Estado en las márgenes”. En Identidades culturales y formación del Estado en Colombia. Colonización, naturaleza y cultura, editado por Ingrid Johanna Bolívar, 119-208. Bogotá: Ediciones Uniandes.

Yie Garzón, Maite. 2018. “iVea los campesinos aquí estamos! Etnografía de la (re)aparición del campesinado como sujeto político en los Andes nariñenses colombianos”. Tesis doctoral en Antropología, Instituto de Filosofía y Ciencias Humanas, Universidade Estadual de Campinas, São Paulo. 